\title{
Empirical Analysis of Marketing Mix Strategy and Student Loyalty in Education Marketing
}

\section{Ogunnaike, O. Olaleke (Ph.D)}

Department of Business Management College of Development Studies, School of Business, Covenant University, PMB 1023, Ota, Ogun State, Nigeria. Email: olaleke.ogunnaike@covenantuniversity.edu.ng

Taiye Tairat Borishade

Department of Business Management, College of Development Studies School of Business, Covenant University, Pmb 1023, Ota, Ogun State, Nigeria.

Email: taiye.borishade@covenantuniversity.edu.ng

Sholarin Adeniyi (Ph.D)

Department Of Human resource development, Covenant University, Ota, Ogun State, Nigeria adeniyi.sholarin @covenantuniversity.edu.ng

\section{Odubela Oyeyemi Omolade}

Department of Business Management, College of Development Studies School of Business, Covenant University, Pmb 1023, Ota, Ogun State, Nigeria.

\section{Doi:10.5901/mjss.2014.v5n23p616}

\section{Abstract}

This study examines the impact of marketing mix strategies on student loyalty. The objectives of the study are to determine the relationship between instructional quality and active participation of the student, to examine the significant relationship between the competence of faculty and staff of the university, to determine if the distribution strategy of a university affects the repeat purchase retention of the students and willingness to recommend the university to others. The study uses survey method with four hypotheses which were later tested with correlation and regression test statistics. Findings show that there is a significant relationship between the impact of the marketing mix and student loyalty. The study recommends that there is a need for institutions to train their staff on how to maximize the use of the marketing mix to the institutions advantage; there is a need for an institution to be highly proactive in tracking customers' feelings.

Keywords: Marketing mix, Student loyalty, distribution strategy, Repeat purchase, Willingness to recommend.

\section{Introduction}

The main purpose of marketing is to meet and satisfy target customers' needs and wants better than other competitors. Marketing is a kind of course needed by everyone in business for the attainment of individual and organizational goals. According to Kotler (2005) marketing mix is the set of controllable tactical marketing tools-product, price, place and promotion-that the firm blends to produce the response it wants in the target market. The marketing mix is often crucial when determining a product or brand's offering, and is often synonymous with the four P's: price, product, promotion, and place; in service marketing. However, the four Ps have been expanded to the Seven P's to address the different nature of services. Additional three P's that were added to the above 'Ps' are People, Process and Physical evidence. Without this marketing mix in business, it will be difficult to achieve the organizational goals.

Higher education is increasingly recognized as a service industry, placing greater emphasis on meeting the expectations and needs of its participating customers, who are the students (Oscar, et al 2005). According toAstin (1993), just like any form of business, issues associated with satisfaction levels and students' perceptions of quality will attract and retain students. Astin (1993) also showed that there is a "direct relationship between student satisfaction and retention. For any business to be successful in today's increasingly competitive marketplace, it must provide a quality product that satisfies customer needs, offer affordable price, and engage in wider distribution and back it up with an effective promotion strategy. (Owomoyela, et al 2013). Thus, many institutions have agreed on aggressive marketing 
activities and movement towards market-orientation by concentrating on student needs (Ivy, 2001). Nevertheless, one of the challenges faced by higher educational institutions is catering to the needs of an increasingly diverse group of students that include a growing segment of more mature students from nontraditional backgrounds, international students, and students who enroll to achieve very specific objectives(Mavondo, Tsarenko, and Gabbot, 2004; Veloutsou, Lewis, and Paton, 2004; Lundberg, 2003; Chronicle of Higher Education Almanac, 2000). The marketing mix consists of everything the educational sector can do to influence the demand for its product. There is also an increase in the perception of the consumers of the term 'quality' on the services recommended by the educational sectors. The relationship between customer satisfaction and service quality has also undergone a good deal of attention.

\section{Statement of Problem}

Looking into the present Educational sector and with heavy competition at hand, there is a major need for effective and efficient marketing mix strategy for all educational sectors in order to generate a good result. Competitive pressures are intensifying. New schools are emerging as they seek to make themselves more competitive.

There is a problem of incompetent faculty and staff; this has resulted in the inability and inadequate capacity required by the faculty and staff to carry out their functions. This hinders their ability to effectively provide adequate educational services. Another important factor to be noted is the poor insufficient salary that the faculty receives, which leads to lack of motivational drive and nonchalance amongst faculty and staff.

Gülbahar (2008) in his study found that although pre-service teachers are willing to use technology, but this hardly occurred because of the inadequacy of lessons to facilitate them with necessary skills to be technologically competent. It has been discovered that in Nigeria, ICT usage among lecturers in the university continues to be terribly minimal.Juwah and Northcote (2002) in their study found that the reasons adduced by staff for lack of relevant ICT skills include lack of time to attend staff development activities as a result of other work commitments, previous bad experience in IT training and fear of technology.Finally, there is a problem of poor infrastructural facilities which includes lack of laboratories, inadequate equipment and dilapidated building. This problem has hindered the student's ability to perform adequately as desired and the lecturer's attitude and performance as there is non-availability of adequate teaching materials, nonavailability of equippingclassrooms, libraries and laboratories.

Education system in Nigeria today, needs a total restructuring; this reform is required to improve the performance of higher education in the country. It is against this backdrop that this study examined the impact of marketing mix strategies on student loyalty.

\section{Objective of the Study}

1. To determine the relationship between instructional quality and active participation of the student.

2. To examine the significant relationship between the competence of faculty and staffof the university and student willingness to recommend a university to others.

3. To determine if the distribution strategy of a university affects the repeat purchase intention of the students.

4. To ascertain if there is a relationship between the physical evidence of a university and a student's willingness to recommend a university to others.

\section{Literature Review}

A student can be referred to as a consumer, regardless of the peculiarity of this description due to the nature of education. They consume educational services just like any other and, thus, can be studied as a consumer of educational services. Though students are called customers because of the student-teachers relationship the fact is there is no educational institution without student's involvement. Loyal students are influencing teaching quality positively through active participation and a committed behavior (Rodie and Kleine, 2000).

The term "marketing mix" was first used in 1953 when Neil Borden, in his American Marketing Association presidential address, took the recipe idea one step further and coined the term "marketing-mix". A prominent marketer, E. Jerome McCarthy, suggested a 4 P's classification in 1960, which has been commonly used.Booms and Bitner extended the $4 p$ 's to 7 p's by adding three more P's which are people, process and physical evidence. This 3P's makes the service more tangible. 


\section{Product}

According to Kotler and Armstrong (2006), a product is anything that attracts attention, acquisition, use or consumption and that might satisfy a want or need".Product can be tangible good or intangible serviced. Examples of tangible products are goods like cell phone, television, etc.Intangible products or services like health treatment by a doctor, legal advice of a lawyer. Therefore, educational services are intangible product that is, a teacher tutoring the students. Product In education marketing is allied to school facilities such as training labs, libraries and workshops. "Universities with the same products will find their markets and public differentiating between them on the basis of their product and their quality" (Kotler \& Fox, 1995). There is a strong relation between the product offered and the institution, as it establishes the institution's identity. Gibbs and Knap (2002) "describe that such identity positions the institution in mind of its customers and determines how the customers will respond to what is being offered".

\section{Price}

Price stimulates a vital part in the marketing mix, thereby captivating consumers and also providing income to institutions. Price is the value or amount of money that a buyer exchanges for a product orservice,provided by the organization. Lamb et al. (2004) "define prices as that which is given up in exchange to acquire goods and services".

\section{Promotion}

There is a need for educational institutions torelateto their target market and publics, they must notify parent and students about theirobjectives and activities in order to inspire them to be interested in their institution. In starting a business which includes educational sector or non- profit organization requires making good decisions which can affect the marketing strategies. One vital area which demands proper reaction is the promotional strategies, educational institutions must initiate promotional policies to encourage its target audience and of its existence of its organization and the service they offer. "Promotion may be a key portionof the school of the marketing mix. Indeed, most marketing efforts that perform at schools are classified as promotion" (Oplatka and Jane, 2004).

\section{8. $\quad$ Place (Distribution)}

Place under marketing mix involves all company activities that make the product available to the targeted customer (Kotler, 2004). Distribution can be described as an act of making product and services available for the customers for easy patronage. In most cases, service providers engage direct marketing approach in distributing their services to the customer (Strydom et al., 2000).

In higher education marketing, place (distribution) simply refers to the availability and the accessibility of the school to its stakeholders. According to Kotler\& Fox(1995), an example of delivery mode for education services is for the institution to present courses at one location, with students gathering for classroom instruction.

\section{Physical Evidence}

University facilities and buildings can be considered physical evidence." Kotler and Fox (1995) also believe that the first image in the university student's mind will be shaped by this Factor". Ivy (2004) considers video projectors and facilities necessary to present lectures as physical evidence. "Infrastructural facilities like computer center, libraries are also very vital. Most courses require the constant use of computers, internet and software applications and the presence of modern and adequate computer and library facilities enhances the satisfaction levels of the students (Rodney Arambewela and John Hall, 2009)".

\section{People}

People are the most important element of any service or experience. Services tend to be produced and consumed at the same moment, and aspects of the customer experience are altered to meet the 'individual needs' of the person consuming it. "According to Goldsmith (1999:181), personnel or people are all those who play a part in the production and delivery of a service. Soedijati and Pratminingsih (2011) believe, it is related to the ability, skills, experience and knowledge of teachers that is the competence of the faculty and staff. Recruiting the right staff and training them 
appropriately in the delivery of their service is essential if the organization wants to obtain a form of competitive advantage. Staff should have the appropriate interpersonal skills, aptitude, and service knowledge to provide the service that consumers are paying for.

\section{Process}

Process is another component of the extended marketing mix, or 7P's. Webber (2005) sees the process as the way in which the user gets hold of the service. 'Goldsmith (1999) defines the process as the procedures which the buyers acquire and use the product, thus all the activity involved in producing and delivering the service". There are a number of perceptions of the concept of process within the business and marketing literature. Processes are all the administrative and bureaucratic functions of the university which is registration, course evaluation, examinations, result dissemination and graduation (Ivy, 2004). Moreover Soedijati and Pratminingsih (2011) consider the learning process and social activities as Processes that occur in universities."Policies, procedures, mechanisms, employee discretion, customer involvement, customer direction and flow of activities are all part of the process of education (Rafiq \& Ahmed, 1995)".

Service Quality

According to Grönroos (1991), companies have to define their quality in the same way as their customers define it, or the companies might act in a wrong way. According to Grönroos (2002), service quality consists of two parts; expected and perceived service. The perceived quality has two scopes, one technical and one functional. The technical dimension is anything the customers get, for examplewhen unsatisfied customers get complaints handled. The customers can regularly measure this dimension because it involves technical solution to a problem. The functional dimension is how the customer gets the service facilitated or handled. For example, how do the personnel behave when they meet their customers? Grönroos (2002) claims that the companies' image and profile work as a filter for the customers' perceived quality. The quality affects the customer perceived value, which is the strongest factor that affects the relation between the customer and the company. (Blomqvist et al, 2000)

Customer Satisfaction

A broad definition of customer satisfaction is "that it is an emotional response to the use of a product or a service: and it is also a complex human process, which involves cognitive and affective process, as well as other psychological and physiological influences" (Chu, 2002, page 285). Kotler et al (1996) say that customer satisfaction depends on a product's or a service's perceived performance in delivering value relative to the buyer's expectations. If the performance of the product or service does not agree to the customer's expectations, the buyer is dissatisfied. If performance matches expectations, the buyer is satisfied. If the performance surpasses expectations, the buyer is highly satisfied.

Student Loyalty

\section{What is Customer Loyalty?}

Customer loyalty can be defined as repeat purchase behavior, which is influenced by a customers' favorable attitude toward a product or service (Kotler \& Keller, 2009).Customer loyalty is the customer continuous purchasing behaviors of the merchandise or service of a certain company (Day, 1977; Griffin, 1996).

According to Oliver, (1999), customer loyalty has been defined as a customer deep commitment to patronize product or service frequently in future, thereby causing repetitive same-brand despite situational influences and marketing efforts having the potential to cause switching behavior.

Student loyalty is one of the key objectives of educational institutions. It has been observed that higher education institutions with loyal student populace always have competitive hedge over others. Performance measurement is so important for all organizations, including educational institutions. With the high costs of education all over the world, there are collective levels of investigation by parents, students and potential employers of the worthprovided by the educational institutes. Institutions are gradually identifying that higher education is a service industry, and are placing more prominence on meeting the opportunities and needs of their contributing customers, which are, the students.(Sam Thomas, 2011)

"Reichheld (1996) thought if a customer was satisfied with companies' commodities or services they would want to offer positive word of mouth promoting that company. Improving customer loyalty in the service enterprises will increase economic benefits". 'Therefore, keen competition in service and improved management and marketing strategies must be aimed at retention not acquisition" (Dwyer, Schurr, Oh, 1987).

Service quality is known as a major performance measure ofdistinction in education and is the key strategic variable for universities as service providers (Donaldson and Runciman, 1995), with stable effects on the institution and 
the students it helps.

Although one might find it difficult to call students "customers" probably because of the teacher-student relationship, the point is that without students, there would be no necessity for educational services. "The customer loyalty is manifested in different ways, including a commitment to re buy or patronize a preferred product or service" (Oliver, 1997; Reichheld and Sasser, 1990; Dick and Basu, 1994). LoyalStudent has both long term and short term impact on the educational institution. Loyal students also influence teaching quality positively by participating actively with aloyal behavior (Rodie and Kleine, 2000).

Some important factors in driving student loyalty are:

- Teaching quality and the role of the teaching staff:

Lecturers are the principal contact with the students, whether in academic and non-academic matters. The response from lecturers,the ability to approach the lecturers easily and the lecturing quality are significant variables that will influence student satisfaction. McManus (2006) established that educational institutions must know student expectations in such areas in order to provide a suitable learning environment for them. The universities also need to adopt non-traditional teaching techniques to satisfythe exact pedagogical demands of the course (Davies, 2007).

- Social life

Social life is also one best important aspect of satisfying student. For example,the social event,the counseling service, and close relationships with other students are well-thought-out variables within the social construct that encourage the satisfaction of students. Most of the students see social networking and interaction with the outside world, as a main part of their learning skill. Also, social support from friends and seniors can help the students to handle academic stress better (Dunn, 2001).

- The academic institutions

Institutions should also consider support services in order to increase student satisfaction. These services include, hotel,job placement support, canteen etc. "Lack of opportunities for employment can be a source of dissatisfaction for the professional students even when they undergo an excellent academic program (Burke, 1986)". The students expect food and accommodation to be made reachable in the campus at reasonable cost. Food and accommodation are rated as important factors influencing student satisfaction (Townley, 2001; Harvey, 2001).

- The infrastructural facilities

Infrastructural facilities like library and computer Centre and are very vital. "Most courses require the constant use of computers, internet and software applications and the presence of modern and adequate computer and library facilities enhances the satisfaction levels of the students" (Arambewela R. and John Hall, 2009).

\section{Theories on Customer Loyalty}

Expectation-confirmation theory will be considered under customer loyalty. This theory posits that expectation, coupled with perceived performance, lead to post purchase satisfaction. This effect is mediated through positive or negative disconfirmation between expectation and performance. "Post purchase satisfaction will result if a product or service falls short of expectation (negative disconfirmation) the customer is likely to be dissatisfied (Oliver, 1980; Sprengetal. 1996)". The(4) main constructs in the model are: expectation, perceived performance, Disconfirmation and satisfaction. They are predictive indicating expected product attributes at some point in the future (Spreng et al. 1996). 'The expectation serves as the comparison standard in what consumers use to evaluate performance and form a disconfirmation judgment (Halstead. 1999)'.

The Diagram Below is Used to Illustrate the Expectation-Confirmation Theory:

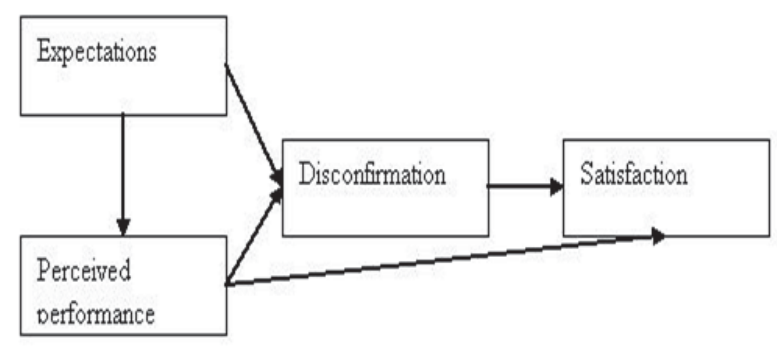

Source: Oliver $(1977,1980)$ 
The term relationship marketing (RM) was originally proposed by Berry in 1983: "attracting,maintaining and in multiservice organizations, enhancing customer relationships" [Little and Marandi, 2003; Grönroos, 2004; Harker and Egan, 2006]. Relationship marketing involves the development of long-term relationships between the customers and the suppliers, in order to create advantages for all those involved and to allow the co-creation of value rather than its unilateral distribution.

\section{Operationalization of Research Variables}

The diagram below shows the relationship amongst the variables:

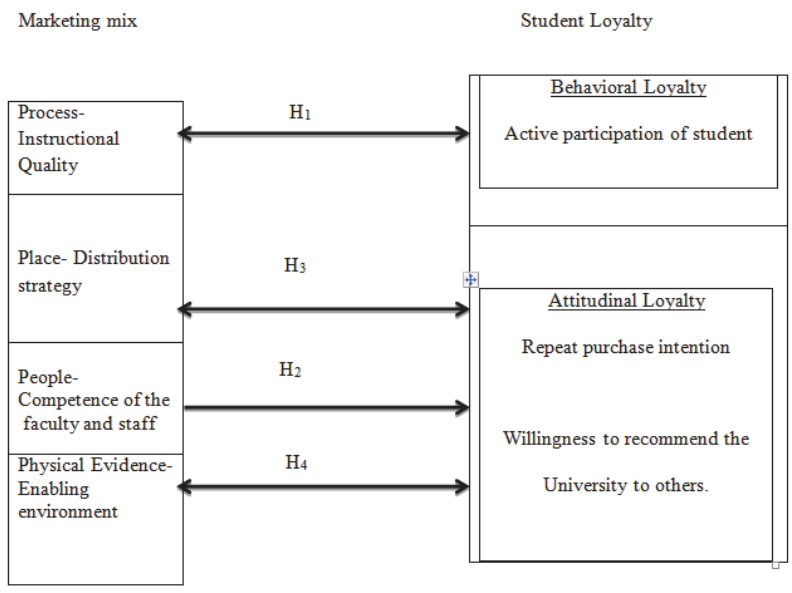

SCHEMATIC MODEL OF THE STUDY

\section{Methodology}

The study adopted descriptive survey research design, in which questionnaire was employed in collecting data form the respondents on the variables studied.The population of study comprised of 522 students who were students of the department of Business Management in a private university. The samples of the study comprised 226 students randomly selected from 100 level to 400 level from the department of business management. Yard formula was employed in the determination of the sample size.

The questionnaire was the instrument used for this study. The questionnaire was divided into three sections; the first section contains personal information of the respondents which includes gender, age, marital status, educational level, program/course, educational level. While the second section contained questions relating to marketing mix strategies for educational services which was divided into four sub-components which includes instructional quality (process), competence of faculty and staff (people), distribution strategies (place) and physical environment (physical evidence). The third section contained questions relating to student loyalty. The questionnaire was formatted on a fivepoint Likert scale ofstrongly disagree (SD), Disagree (D), undecided (U), agree (A), strongly agree (SA).The Cronbach's alpha test was used to test the reliability of the research instrument.

Copies of the questionnaire were distributed by the researcher Out of the 226 copies administered, 194 were retrieved for analysis which represented $86 \%$ of the total. Data were analyzed using Pearson correlation coefficient to examine the relationship and regression to examine the effect between student loyalty (dependent variable) and marketing mix. (Independent variable).

\section{Testing of Hypotheses}

Hypothesis 1

$\mathrm{H}_{0}$ : There is no relationship between instructional quality and active participation of the student. 
Table 1: Correlations

\begin{tabular}{|cc|c|c|}
\hline & & Process & Active participation \\
\hline \multirow{3}{*}{ Process } & Pearson Correlation & 1 & .059 \\
& Sig. (2-tailed) & & .411 \\
N & 194 & 194 \\
Active participation & Pearson Correlation & .059 & 1 \\
& Sig. (2-tailed) & .411 & \\
N & 194 & 194 \\
\hline
\end{tabular}

Source: Field Survey, 2014.

Coefficient of Determination (C.O.D)

The coefficient of determination is obtained using formula C.O.D $=r^{2} \times 100 \%$

Where $r=$ Pearson Correlation

Thus;

C.O.D $=(0.059)^{2} \times 100 \%$

C.O.D $=0.003481 \times 100 \%$

C.O.D $=0.35 \%$

Hypothesis 2

$\mathrm{H}_{0}$ : There is no significant relationship between the faculty and staff competence of the university and student willingness to recommend a university to others.

Table 2: Correlations

\begin{tabular}{|cc|c|c|}
\hline & & People & Willingness to recommend \\
\hline & Pearson Correlation & 1 & $.186^{*+}$ \\
& Sig. (2-tailed) & & .009 \\
People & $N$ & 194 & 194 \\
& Pearson Correlation & $.186^{\text {** }}$ & 1 \\
\multirow{2}{*}{ Willingness to recommend } & Sig. (2-tailed) & .009 & \\
& $\mathrm{~N}$ & 194 & 194 \\
\hline
\end{tabular}

Source: Field Survey, 2014.

C.O.D $=(0.186)^{2} \times 100 \%$

C.O.D $=0.034596 \times 100 \%$

C.O.D $=3.46 \%$

\section{Discussion of Results}

The results from table 1 show that there is a significant positive correlation of $(0.059)$ between both variables at 0.411 level of significance. Thus, as obtained from the table $\{r=0.059, p>0.05, n=194\}$. The results from table 2 above show that there is a significant positive correlation of $(0.186)$ between both variables at 0.009 level of significance.

Thus, as obtained from the table $\{r=0.186, p<0.05, n=194\} .0 .35 \%$ shared variance between instructional quality and active participation of the student and $3.46 \%$ shared variance between faculty and staff competence of a university and student willingness to recommend a university to others.

Hypothesis 3

$\mathrm{H}_{0}$ : The distribution strategy does not have a significant effect of the repeat purchase retention of the student. 
Coefficients $^{a}$

\begin{tabular}{|c|c|c|c|c|c|}
\hline \multirow{2}{*}{ Model } & \multicolumn{2}{|c|}{ Unstandardized Coefficients } & Standardized Coefficients & \multirow{2}{*}{$\mathrm{T}$} & \multirow{2}{*}{ Sig. } \\
\hline & $B$ & Std. Error & Beta & & \\
\hline (Constant) & 3.619 & .302 & & 11.973 & .000 \\
\hline Place 14 & .018 & .087 & .016 & 211 & .833 \\
\hline Place 15 & -.398 & 122 & -.253 & -3.258 & .001 \\
\hline Place 16 & .250 & .140 & 138 & 1.782 & 076 \\
\hline $\mathrm{R}$ & .240 & & & & \\
\hline $\mathrm{R}^{2}$ & .058 & & & & \\
\hline Adj. $R^{2}$ & .043 & & & & \\
\hline $\mathrm{F}$ & 3.887 & & & & \\
\hline Overall Sig. & .010 & & & & \\
\hline
\end{tabular}

The table seeks to explain which of the variables is making a statistically significant(sig=0.010), in which the F-value is equal to 3.887, and the significant value is less than 0.05. Looking at the sig column in the table; it reveals that distribution strategy has a significant effect on repeat purchase intention of the student. The implication of this result is that the distribution strategy has a significant effect of the repeat purchase intention of the student.

Hypothesis 4

$\mathrm{H}_{0}$ : There is no significant relationship between the physical environment of a university and a student willingness to recommend a university to others.

\begin{tabular}{|c|c|c|c|}
\hline & & Willingness to recommend & physical \\
\hline \multirow{3}{*}{ Willingness to recommend } & Pearson Correlation & 1 & $.347^{* *}$ \\
\hline & Sig. (2-tailed) & & .000 \\
\hline & $\begin{array}{c}\mathrm{N} \\
\text { Pearson Correlation }\end{array}$ & $\begin{array}{l}194 \\
.347^{+*}\end{array}$ & $\begin{array}{c}194 \\
1\end{array}$ \\
\hline \multirow[t]{2}{*}{ Physical evidence } & Sig. (2-tailed) & .000 & \\
\hline & $\mathrm{N}$ & 194 & 194 \\
\hline
\end{tabular}

Source: Field Survey, 2014.

C.O.D $=(0.347)^{2} \times 100 \%$

C.O.D $=0.120409 \times 100 \%$

C.O.D $=12.04 \%$

\section{Discussion of Results}

The results from the table above show that there is a significant positive correlation of $(0.347)$ between both variables at 0.001 level of significance and $12.04 \%$ shared variance between physical environment of a university and student willingness to recommend a university to others as obtained from the table $\{r=0.347, p<0.05, n=194\}$.

\section{Conclusion/ Recommendation}

Based on the result of this study, it is established that there is a positive relationship between instructional quality and active participation of students. Based on the findings, it is suggested that Institutions need to know the basic communication process to ensure that they convey the right message through the right medium to student in such a way that they can understand and respond to it.It was discovered that for an organization to be able to meet the specific requirements of the consumers of its products and services, there is the need for the adoption and implementation of marketing mix elements. This brings about a shared set of beliefs and values that puts the consumer in the center of the firms thinking strategy and operations. Marketing mix which is an organizational wide culture dedicated to delivering superior customer value brings about the production of goods that are carefully researched and designed to appeal to 
customers in the market.With the above understanding of marketing mix, the existing relationship between marketing mix and consumer loyalty can be said to be indisputable. That is to say, a better implementation of marketing mix elements especially Physical evidence, Process and People would lead to frequent purchase of University's admission form and finally,marketing mix play a crucial role in enhancing the behavior of people and their proper application and implementation by the university will lead to achievements of optimal results and ultimately higher standards of consumer's loyalty.

\section{References}

Arambewela, R., \& Hall, J. (2009). An Empirical Model of International Student Satisfaction. Asia Pacific Journal of Marketing and Logistics, 21(4), $555-569$.

Astin, A.W. (1993). What Matters in College? Four Critical Years Revisited. San Francisco: Jossey-Bass.

Berry, L. L. (1983). Relationship Marketing: In Emerging Perspectives on Services Marketing, ed. Leonard L. Berry, G. Lynn Shostack, and Gregory Upah, pp. 25-28 Chicago: American Marketing Association.

Blomqvist, R., Dahl, J., \& Haeger, T. (2000). Relationsmarknadsföring Vinnande strategi en ny ekonomi Göteborg: IHM Förlag.

Booms, B. H., \& Bitner, M. J. (1981). Marketing Strategies and Organization Structures for Service Firms, in Donnelly, J., H., and George, W.,R., (eds). Marketing of Services.Chicago:American Marketing Association.

Borden, N.H. (1964). The Concept of the Marketing Mix. Journal of Advertising Research, 24(4), 7-12.

Burke, B.D. (1986). Experience of overseas undergraduate students, Bulletin No. 18, University of New South Wales.

Chronicle of Higher Education (2000).Almanac Issue, 67(1).

Chu, R., (2002). Stated-Importance versus Derived-Importance Customer Satisfaction Measurement, Journal of Services Marketing, 16(4), 285-301.

Davies, R. (2007), Traditional Education Not That Bad,The Jakarta Post, 14 April 2007, [Online] retrieved April 19,2007,

Day, R. L. (1977). Extending the Concept of Consumer Satisfaction. Advances in Consumer Research, 4(1), 149-154.

Donaldson, B., \& Runciman, R. (1995), Service Quality in Further Education: An Insight into Management Perceptions of Service Quality and those of the Actual Service Provider, Journal of Marketing Management, 11(1-3), 243-256.

Dunn, A. (2001). Into the unknown. Education Age, (March7, 2001). 16.

Dwyer, F. R., Schurr, P. H., \& Oh, S. (1987). Developing Buyer-Seller Relationships. Journal of Marketing, 51(2), 11-27.

Gibbs, P., \& Knapp, M. (2002). "Marketing Higher and Further Education : an

Educator's Guide to Promoting Courses", Departments and Institutions. London: Kogan Page.

Grönroos, C. (1991). Strategic Management and Marketing in the Service Sector.Lund:Studentlitteratur

Grönroos, C. (2002). Service Management och Marknadsföring: En CRM ansats.Malmö: Liber AB.

Gulbahar, Y. (2008). Improving the technology integration skills of prospective teachers through practice: A case study, Journal of educational technology, 7(4), 71-81.

Halstead, D. (1999). The Use of Comparison Standards in Customer Satisfaction Research and Management: A Review and Proposed Typology. Journal of Marketing Theory \& Practice, 7(3), 13-26.

Harker, M.J., Egan, J. (2006). The Past, Present and Future of Relationship Marketing, Journal of Marketing Management,22(1/2), 215242.

Ivy, J., \& Naude, P. (2004). Succeeding in the MBA Marketplace: Identifying the Underlying Factors", Journal of Higher Education Policy \& Management, 26(3),401-417.

Juwah, C.,\& Northcote, M.(2002) Devising strategies for enhancing quality staff development in embedding ICT in teaching and learning, in Quality Conversations, Proceedings of the 25th HERDSA Annual Conference, Perth, Western Australia, 7-10 July 2002: pp 384.

Kotler, P.,\& Armstrong, G. (2005).Principles of Marketing, New Jersey, Pearson Education Inc. 10th Edition.

Kotler, P., \& Fox, K.F.A. (1995). Strategic Marketing for Educational Institutions. Prentice-Hall.Upper Saddle River, NJ.

Kotler, P. (2004). Principles of Marketing, New Jersey, Pearson Education.

Kotler, P., Armstrong, G., Saunders, \& J., Wong, V. (1996). Principles of Marketing. London and others: Prentice Hall.

Kotler,P., Keller, K. (2009). Marketing management. New jersey:Person education.

Lamb C.W., Hair,J.F., McDaniel, C., BoshoffC.,\& Terbalancle,N.S. (2004).

Marketing Management. 2nd Edn., Oxford University Press, Oxford.

Little, E., Marandi, E. (2003). Relationship Marketing Management, London: Thomson Learning,

Lundberg C.A. (2003). Non-Traditional College Students and the Role of Collaborative Learning as a tool for Science Mastery, School Science and Mathematics, 103(1), 8-18.

Mavondo, F. T., Tsarenko, Y., \&Gabbot, M. (2004).Intemational and local student satis-faction: resource and capabilities perspective. Journal of Marketing for Higher Educa- tion, 4(I),41-60.

McCarthy, E. J. (1960). Basic Marketing: A Managerial Approach, Irwin.

McCarthy, E. J. (1975) "Basic Marketing: A Managerial Approach", Fifth Edition,

Richard D. Irwin, Inc., p.37. 
McManus, D. (2006). Getting to Know Your Students: Three Challenges, The Teaching Professor, 20(6), 8, [Online] retrieved (April 18, 2007).

Oliver, R. L. (1999). "Whence Consumer Loyalty?" Journal of Marketing, 63(Special), 33-44.

Oliver, R. (1997). A Conceptual Model of Service Quality and Service Satisfaction:

Compatible Goals, Different concepts, Advances in Consumer Research, 21, 16-22.

Oliver, R. L. (1980). A Cognitive Model of the Antecedents and Consequences of Satisfaction Decisions. Journal of Marketing Research, $17,460-469$

Oplatka, I., \&Jane,H.B. (2004). The Research on School Marketing: Current Issues and Future Direction. J. Educ. Admin, 42(3), 375400.

Oscar W. DeShieldsJr, Ali Kara, ErdenerKaynak, (2005) "Determinants of business student satisfaction and retention in higher education: applying Herzberg's two-factor theory", International Journal of Educational Management, Vol. 19 Iss: 2 , pp.128 - 139

Rodie, A.R., \&Kleine, S.S. (2000). Customer participation in services production and Delivery in T.A. Swartz and D. lacobucci (eds.), Handbook of Service Marketing and Management, Sage, Thousand Oaks, CA, pp. 111-125.

Reicheld, F., \&Sasser, W. (1990). "Zero defections: Quality comes into services. Harvard Business Review, 5, 105-111

Reichheld, F. F. (1996). The Loyalty Effect: The Hidden Forces Behind Growth, Profits, and Lasting Value. Boston, M.A.: Harvard Business School Press.

Sam, T. (2011). What Drives Student Loyalty in Universities: An Empirical Model from India, International Business Research, 4(2), 183-

Soedijati, E.K., \&Pratminingsih,S.A. (2011). "The Impact of Marketing Mix on Students Choice of University Study Case of Private University", in Bandung, Indonesia. Proceeding of the 2nd International Conference on Business and Economic Research (2nd ICBER 2011).

Speng, R. A., Mackenzie, S.B., \&Olshavsky, R.W. (1996). A Reexamination of the Determinants of Consumer Satisfaction. Journal of Marketing, 60, 15-32.

Strydom, J., Jooste, C. \& Cant, M. (2000). Marketing Management. Fourth edtion. Cape Town: Juta.

Townley, P. (2001). The construction of a model of qualitative evaluation to support the development of the policy and practice of raising student satisfaction in an institution in the higher education sector, Conference proceedings, Higher Education Close Up Conference 2, Lancaster University,UK, 16-18 July.

Veloutsou, C, Watkins, J. W., \& Paton, R. (2004). University Selection: Information Requirements and Importance, Intemational Journal of Educational Management, 18(3),160-171. 